\title{
Aktivisme på tjekkisk
}

\section{Thomas Hjortsø}

\section{Tjekkiet fører sin helt egen aktivistiske udenrigs-}

politik, der er baseret på dissidenternes erfaring fra den kommunistiske fortid, og som derfor lægger afgørende vægt på støtte til demokratisering, især i tjekkiets nærområde

De er kendt som Havels mafia. De arbejdede for den tidligere systemkritiker, forfatteren Vaclav Havel, da han blev præsident, og nu sidder mange af dem i det tjekkiske udenrigsministerium. Havels mafia arbejder med at fremme demokratiet $\mathrm{i}$ lande med autoritære regimer.

Tjekkiet er måske det land i Østog Centraleuropa, der er mest aktiv med at fremme demokrati. Udenrigsministeriet i Prag har ligefrem en særlig enhed, der arbejder for at fremme demokratiske forandringer.

Men Havels mafia har ikke altid haft det nemt. "Da vi i 1998 kom til det tjekkiske udenrigsministerium med nogle forslag til projekter i Hviderusland, blev vi mødt med en kold skulder. Det er russisk interessesfære, sagde de i ministeriet", fortæller Lubos Vesely.

Han tog så omvejen omkring Vaclav Havels præsidentadministration og blev en del af Havels mafia. Den talte 10-15 ansatte i Havels politiske afdeling, hvor Lubos Vesely ledede arbejdet med menneskerettigheder i Øst- og Centraleuropa. Da Havels anden præsidentperiode løb ud i 2003, kom Lubos Vesely til organisationen Folk i Nød, der spænder meget vidt fra nødhjælp til at fremme demokrati. Han er en af få fra Havels mafia, som ikke er havnet i det tjekkiske udenrigsministerium.

I dag er han ansat i tænketanken AMO, der beskæftiger sig med internationale forhold. Her arbejder han især med et land som Hviderusland. Organisationer som Folk i Nød og AMO er kun to ud af en række tjekkiske NGO'er, der vil fremme demokratiet i autoritære regimer. Flere af dem får også støtte af den tjekkiske stat - ikke mange penge efter danske forhold, men i høj grad efter tjekkisk målestok. 
Det var gennem Vaclav Havels indflydelse som præsident, at Tjekkiet skabte sin aktivistiske udenrigspolitik. Og det spillede en stor rolle, at Havel havde været systemkritiker under kommunismen. Og at Havel som Tjekkiets moralske fyrtårn smed sin vægt bag initiativet.

"Vi har en moralsk pligt til at hjælpe. Vi har selv oplevet et autoritært styre, og mange i for eksempel ministerierne har siddet i fængsel under kommunismen", siger Lubos Vesely. Det har også formet den måde, Tjekkiet fører sin aktivistiske udenrigspolitik på. Enhver tale om eksport af demokrati er bandlyst. "Man kan eksportere varer, men ikke demokrati. Det er nonsens. Vi er ikke ude på vælte nogle regimer," siger Lubos Vesely.

Også det tjekkiske udenrigsministerium understreger, at det ikke er ude på at vælte regimer, men støtter demokratiske kræfter og civilsamfund, selv om forskellen nogle gange kan være hårfin. "Vi forsøger ikke at eksportere demokrati, men vi vil støtte enhver måde at hjælpe et land til at få demokrati”, siger Gabriela Dlouha, der leder udenrigsministeriets særlige enhed, som fremmer demokratiske forandringer. Også hun kom i sin tid fra Havels kontor. Hendes ordvalg skal nok ses i lyset af beskyldninger fra autoritære regimer, som mener, at Vesten styrter regimer i demokrati-eksportens navn for eksempel med Ukraines orange revolution.

\section{Havels store indflydelse}

Hvor meget det betyder for Tjekkiet at fremme demokrati ses af landets officielle hjemmeside. Her står der, at "Tjekkiet bekender sig til arven og værdierne fra europæisk civilisation. Et af dets hovedprioriteter er udviklingen af demokrati og retssamfund baseret på frihed, lighed, retfærdighed, demokrati, tolerance og solidaritet med de svage, truede og forsvarsløse. Det opfatter ikke kun demokrati som enkeltlandes indre anliggender, men også som udgangspunkt for en succesrig udvikling af gensidige relationer."

Og det er altså vigtigt, at der findes nogle demokratiske kræfter, som Tjekkiet kan støtte. Den form for aktivistisk udenrigspolitik afspejler, at Vaclav Havel som en af de få demokratiske kræfter i det gamle Tjekkoslovakiet netop fik vestlig hjælp under kommunismen.

Der gik dog nogle år fra Tjekkoslovakiet blev frit i 1989 til den aktivistiske udenrigspolitik. Ifølge Lubos Vesely var skilsmissen fra Slovakiet i 1993 en af grundene til, at det gik så langsomt.

Også medlemskravene fra NATO og Den Europæiske Union tærede på kræfterne, og det var faktisk først, da medlemskabet af EU var i hus, at Tjekkiet for alvor begyndte at tænke på at støtte demokrati i andre lande. "Det havde også noget at gøre med, at vi endelig følte os som en del af den demokratiske klub", siger Lubos Vesely. 
Tjekkiet har siden fokuseret på demokratiet i Hviderusland, Cuba, Burma og Tibet. Allerede i 1991 pegede Vaclav Havel på den burmesiske oppositionsleder Aung San Suu Kyi som modtager af Nobels Fredspris. Og sidste år opfordrede Havel sammen med den sydafrikanske ærkebiskop Desmond Tutu til, at FN's Sikkerhedsråd lagde mere pres på det militære styre i Burma.

Også forholdet til Tibets religiøse leder Dalai Lama har været præget af Havels person. Han og Dalai Lama har i flere år kendt hinanden. Men Tjekkiet har fortsat sin fokus på Tibet, også efter at Havel forlod præsidentembedet i 2003 - blandt andet med en konference, som blev holdt i Prag på trods af kinesiske protester. Kampen for at fremme demokrati i Tibet har som i de fleste vestlige lande været hæmmet af ønsket om gode økonomiske forbindelser med styret i Kina.

Den højeste profil har kampen for demokrati i Cuba og Hviderusland haft. Og det er også her, Tjekkiet har været i gang længst.

I Cuba blev en tidligere tjekkisk minister, Ivan Pilip, og en tidligere studenterleder, Jan Bubenik, fængslet i tre uger i 2001 for at mødes med to uafhængige journalister. Senere har der været andre episoder med blandt andre en tjekkisk senator, der blev udvist sidste år. Tjekkiet har også presset på i EU for at få unionen til at indtage en mere stejl holdning til Fidel Castros styre. Men
Tjekkiet er stødt på modstand fra lande som Spanien og Frankrig, der blandt andet har økonomiske interesser i Cuba.

Når Tjekkiet er gået forrest i den slags lande, hænger det også sammen med, at opgaven er lettere, fordi Tjekkiet med sin historiske baggrund er befriet for mistanke om, at det har en bagtanke som kolonimagt eller handler ud fra snævre $\varnothing$ konomiske interesser. Tjekkiets aktivistiske udenrigspolitik menes også at være uafhængig af hvilken tjekkisk regering, der er ved magten. Ifølge Lubos Vesely kan en ny borgerlig regering tænkes at øge indsatsen for på det område.

\section{Hviderusland}

Kampen for at fremme demokratiet i Hviderusland er nok den, der står tjekkernes hjerte nærmest. "Det er så tæt på. Vi deler slaviske rødder, og vi har begge været underlagt Sovjetunionen", siger Gabriela Dlouha fra det tjekkiske udenrigsministerium.

Også mellem Tjekkiet og Hviderusland har der været officielle bataljer. En af de mest kendte var i forbindelse med et NATO-topmøde i Prag i 2002, da Hvideruslands autoritære leder, Alexander Lukasjenko, blev nægtet indrejse.

Senere i 2005 udviste de hviderussiske myndigheder Tjekkiets ambassadør i Minsk og beskyldte ham for at depravere mindreårige og opmuntre dem til samfundsskadelig 
virksomhed. Det hviderussiske statslige tv kaldte ham direkte for pædofil. Bag de bizarre hviderussiske beskyldninger lå uden tvivl den tjekkiske støtte til oppositionen i Hviderusland - herunder ungdomsorganisationer. Tjekkiet svarede igen ved at udvise en hviderussisk diplomat.

Også i år har der været problemer mellem de to lande. Tjekkiske diplomater i Hviderusland blev i februar i deres bil standset af civile agenter, fordi de havde brochurer fra $\mathrm{FN}$ om menneskerettigheder. De var tilsyneladende på vej til at dele brochurerne ud. Under præsidentvalget i Hviderusland i marts blev en tjekkisk journalist fra en af de største aviser tævet af, hvad han mener var det hemmelige politi.

Og netop Vaclav Havel blev nægtet tilladelse til at komme ind på den hviderussiske ambassade i Prag for at aflevere en protest mod præsidentvalget, som internationale observatører betegnede som udemokratisk, og som gav genvalg til Lukasjenko med ikke færre end 83 procent af stemmerne.Vaclav Havel skrev i den forbindelse, at jo mere civilsamfund, der findes i Hviderusland, jo lettere bliver overgangen til demokrati, hvis det altså kommer.

\section{Ingen aktivitet i Mellemøsten}

Tjekkiet har også været meget aktiv i støtten til den demokratiske opposition. Senest har Tjekkiet også støttet den europæiske radio for Hviderusland, som ironisk nok er et især amerikansk finansieret projekt om at sende FM-radio til Hviderusland lavet af hviderussiske journalister i udlandet. Både den tjekkiske stat og Havels fond har givet penge til radioen, der synes som et langt bedre alternativ end EU's egne radioudsendelser til Hviderusland. De bliver sendt på kortbølge, som kun få hviderussere kan modtage.

Under den diplomatiske krise mellem Tjekkiet og Hviderusland i 2005 kom Hviderusland med beskyldninger om, at USA og EU ville have sine østeuropæiske satellitstater som Tjekkiet til at udføre det beskidte arbejde i Hviderusland.

De beskyldninger burde snarere have adresse til Polen, som også er meget aktiv i Hviderusland. Men forskellen er, at polske NGO'er i modsætning til de tjekkiske modtager mange penge fra USA, fortæller Lubos Vesely fra tænketanken AMO, der i øvrigt har et samarbejde med en polsk organisation.

Der er en stor sort plet på det tjekkiske verdenskort over støtte til demokrati. Det er Mellemøsten. I modsætning til for eksempel Danmark har Tjekkiet valgt at satse sine penge på en anden måde. "Vi er kun et lille land. Mellemøsten er så stort. Vi skal bruge vores ressourcer dér, hvor de gør mest nytte", siger Lubos Vesely.

Thomas Hjortsø er journalist ved DR's Orientering, P1, med Østeuropa og Balkan som speciale. 